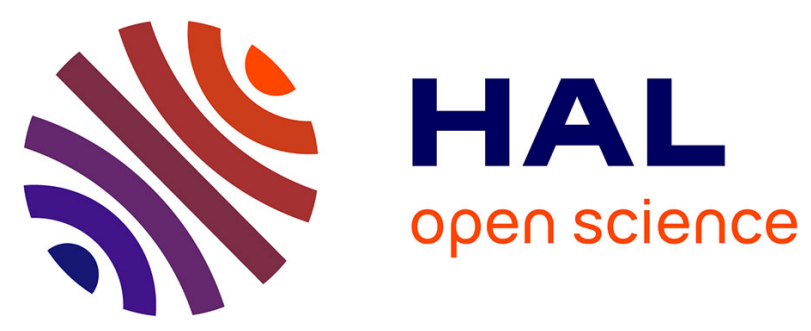

\title{
Reduced bone mineral density in HIV-infected patients: prevalence and associated factors.
}

Charles Cazanave, Michel Dupon, Valérie Lavignolle-Aurillac, Nicole Barthe, Sylvie Lawson-Ayayi, Nadia Mehsen, Patrick Mercié, Philippe Morlat, Rodolphe Thiébaut, Francois Dabis, et al.

\section{To cite this version:}

Charles Cazanave, Michel Dupon, Valérie Lavignolle-Aurillac, Nicole Barthe, Sylvie Lawson-Ayayi, et al.. Reduced bone mineral density in HIV-infected patients: prevalence and associated factors.: Reduced bone mineral density in HIV patients. AIDS. Official journal of the international AIDS Society, 2008, 22 (3), pp.395-402. 10.1097/QAD.0b013e3282f423dd . inserm-00186715

\section{HAL Id: inserm-00186715 https://www.hal.inserm.fr/inserm-00186715}

Submitted on 6 Jul 2009

HAL is a multi-disciplinary open access archive for the deposit and dissemination of scientific research documents, whether they are published or not. The documents may come from teaching and research institutions in France or abroad, or from public or private research centers.
L'archive ouverte pluridisciplinaire HAL, est destinée au dépôt et à la diffusion de documents scientifiques de niveau recherche, publiés ou non, émanant des établissements d'enseignement et de recherche français ou étrangers, des laboratoires publics ou privés. 


\title{
Full title: Reduced bone mineral density in HIV-infected patients: prevalence and associated factors, ANRS CO3 Aquitaine cohort
}

\section{Short title: Reduced bone mineral density in HIV patients}

\author{
Cazanave $C^{\mathrm{a}}$, Dupon $\mathbf{M}^{\mathrm{a}}$, Lavignolle-Aurillac $\mathrm{V}^{\mathrm{b}}$, Barthe $\mathrm{N}^{\mathrm{c}}$, \\ Lawson-Ayayi $S^{b, g}$ Mehsen $N^{d}$, Mercie $P^{b, e}$, Morlat $P^{b, f}$, Thiébaut $\mathbf{R}^{b}$, \\ Dabis $F^{b, g}$ and the Groupe d'Epidémiologie Clinique du SIDA en \\ Aquitaine (, $^{\text {,* }}$
}

2984 words (except abstract, acknowledgements, appendix and references).

From ${ }^{a}$ Fédération de Maladies Infectieuses et Tropicales, Hôpital Pellegrin, Centre Hospitalier Universitaire (CHU), Bordeaux, France, ${ }^{\mathrm{b}}$ INSERM U593, ISPED, Université Victor Segalen, Bordeaux, France, 'Service de Radiologie, Hôpital Pellegrin, ${ }^{\mathrm{d}}$ Service de Rhumatologie, Hôpital Pellegrin, ${ }^{\mathrm{e}}$ Service de Médecine Interne et Maladies Tropicales, Hôpital Saint-André, CHU, Bordeaux, ' Service de Médecine Interne et Maladies Infectieuses, Hôpital Saint-André and ${ }^{\mathrm{g}}$ Centre d'Information et de Soins de l'Immunodéficience Humaine (CISIH), CHU, Bordeaux.

*Composition of the GECSA (Groupe d'Epidémiologie Clinique du SIDA en Aquitaine):

- GECSA-TISSOS Study-Group: Cazanave C, Dupon M, Lavignolle-Aurillac V, Barthe N, Lawson-Ayayi S, Dutronc H, Mehsen N, Schaeverbeke T, Mercie P, Morlat P, Pellegrin JL, Thiébaut R and Dabis F.

- Coordinator: F. Dabis.

Epidemiology and Methodology: G. Chêne, F. Dabis, S. Lawson-Ayayi, C. Lewden, R. Thiébaut. Infectious diseases and Internal medicine: M. Bonarek, F. Bonnal, F. Bonnet, 
N. Bernard, O. Caubet, L. Caunègre, J. Ceccaldi, C. De La Taille, S. De Witte, M. Dupon, H. Dutronc, S. Farbos, T. Galpérine, K. Lacombe, D. Lacoste, S. Lafarie, P. Loste, D. Malvy, P. Mercié, P. Morlat, D. Neau, A. Ochoa, JL. Pellegrin, JM. Ragnaud, S. Tchamgoué, JF. Viallard. Immunology: P. Blanco, JF. Moreau. Virology: H. Fleury, ME. Lafon, B. Masquelier, I. Pellegrin. Pharmacology: D. Breilh. Pharmacovigilance: G. Miremont-Salamé. Data collection and Data management: E. Balestre, MJ. Blaizeau, M. Decoin, S. Delveaux, S. Geffard, C. Hannapier, S. Labarrère, V. Lavignolle-Aurillac, B. Uwamaliya-Nziyumvira. Data processing: G. Palmer, D. Touchard.

Correspondence to Charles Cazanave, Fédération de Maladies Infectieuses et Tropicales, Hôpital Pellegrin, Place Amélie Raba-Léon, 33076 Bordeaux cedex, France. Tel: +335 567955 23; fax: +33505 567961 73; e-mail: charles.cazanave@chubordeaux.fr 


\section{Introduction}

Highly active antiretroviral therapy (HAART) has drastically improved the prognosis of patients infected with HIV [1]. Long-term HAART is associated with several metabolic and morphological complications, including lipodystrophy, insuline resistance, diabetes and dyslipidemia [2]. Accelerated bone mass loss, osteopenia and osteoporosis, have recently been described in HIV-infected subjects, particularly in middle-aged men, with variable prevalence estimates [3, 4], mostly due to limited sample sizes and possible selection of patients. A recent meta-analytic review had showed a prevalence of osteoporosis of $15 \%$ in HIV-infected individuals, 3.7 times greater compared with HIVuninfected controls [5]. Underlying mechanisms leading to theses complications are still unclear and thought to be multifactorial [3-13]. Multiple factors thought to be associated with bone metabolism in HIV-infected patients have been sparsely studied, including the long-term use of HAART with inconclusive results [3, 12]. Among the possible causes of osteoporosis that have been considered, the possible direct effect of HIV upon osteogenic cells, the persistent activation of pro-inflammatory cytokines and the alterations in the metabolism of vitamin $\mathrm{D}$ have been most often quoted but remain at the stage of scientific hypothesis [14-18].

The aim of the present study is to accurately estimate the prevalence of reduced bone mineral density (BMD) in a large cohort with unrestricted enrolment of French, multirisk, both gender HIV-1 infected patients and to investigate in a systematic manner factors associated with such disorders. 


\section{Methods}

\section{Study population}

We carried out a cross-sectional survey within the ANRS CO3 Aquitaine cohort. The Aquitaine cohort is an open and dynamic prospective hospital-based cohort of HIV-1infected patients under routine clinical management in South Western France [19], initiated in 1987 in the Bordeaux University Hospital and four other public hospitals in this region by the Groupe d'Epidémiologie Clinique du Sida en Aquitaine (GECSA). Inclusion criteria are: all adults who attend in- or out-patients services of the participating hospitals, with HIV-1 infection confirmed by Western blot testing, regardless of clinical stage, and with either at least one follow-up after the first clinic visit or with a known date of death, and having given informed consent.

Patients were included consecutively in the present study between November 2004 and May 2005. Patients were eligible if they were still alive and followed on November $1^{\text {st }}$, 2004, without chronic kidney failure (creatinine clearance $<70 \mathrm{~mL} / \mathrm{min}$ ), liver failure (prothrombine rate $<70 \%$ ) or prolonged immobilization ( $>30$ days). Written informed consent was obtained from all participants for this specific study.

Patients characteristics including gender, age, HIV transmission group, date of HIV diagnosis and AIDS stage according to US Centers for Disease Control (CDC) and Prevention classification, hepatitis B and C virus serological status, alcohol and tobacco consumption, medications intake, type and duration of specific antiretroviral classes used, including nucleoside and nucleotide reverse transcriptase inhibitors (NRTIs), nonnucleoside reverse transcriptase inhibitors (NNRTIs) and protease inhibitors (PIs). All these variables were extracted from the cohort data base and checked with medical records. A specific questionnaire was filled during the first clinic visit during the study period to document body mass index (BMI), calcium consumption and physical activity, a physical activity (professional or leisure) $>30$ minutes per day was considered sufficient. 


\section{Bone mineral density assessment}

Total mean body mass density (BMD) and total mean T-score of total body, lumbar spine and femoral neck were measured by DEXA scans [Hologic ${ }^{\mathrm{TM}}$, Bedford, CT, USA] by a single radiologist. The study equipment was registered in a French centralized quality control program validated by the Groupe de Recherche et d'Information sur les Ostéoporoses (GRIO). This control included a daily phantom scan allowing follow up of the stability of BMD over time, the use of Shewhart rules and Cusum tests to monitor changes in scanner performances. A regular checking was made, by the manufacturer to verify the scanner's precision and ensure examinations reproducibility with a calibration error $<0.5 \%$. The coefficient of variation of phantom BMD was evaluated at $0.42 \%$, for the study period. The unit of measurement was the Tscore, i.e. the standard deviation (SD), interpreted by comparison with the maximum value reached by young adults (30 years) of the same sex. Measurement was made on the total body to explore the bone mass, the fatty mass and the lean mass and on two specific anatomic sites, the femoral neck which allows a quantitative evaluation of cortical bone tissue and the lumbar spine, L2 to L4, which allows a quantitative evaluation of trabecular bone tissue.

The database used for women to assess T-scores was the French database (ISOS, OFELY and GENSET studies), validated by the GRIO. For men, reference curves for the total body and the femoral neck were lacking in France, and the American databases (TK curves) were used for the femoral neck, the lumbar spine and the total body [20].

The World Health Organisation (WHO) classification was used for diagnosis purposes [21]. Osteopenia was defined as a T-score between -1 and $-2.5 \mathrm{SD}$, and osteoporosis was defined as a T-score less than $-2.5 \mathrm{SD}$.

\section{Laboratory methods}

HIV plasma RNA levels were measured by real-time PCR using the COBAS AmpliPrep/Cobas TaqMan HIV-1 Test $^{\circledR}$, and $\mathrm{CD}^{+}$cell counts using the flow cytometer. 


\section{Statistical analysis}

Prevalence of bone abnormalities at the time of the study was estimated for each diagnostic category, dividing the number of patients fulfilling the above diagnostic criteria by the total of patients screened. We stratified the data according to gender because references differed according to this factor (see above). A multivariable analysis using polytomous logistic regression appreciated factors associated with the presence of osteopenia or osteoporosis. Variables with $p<0.25$ in univariable analyses were included in the full models. The final models were selected by using a stepwise descending procedure. Fits of final models were checked by Hosmer and Lemeshow Chi-squared test. Analyses were processed with the use of SAS software (SAS Institute, Cary, NC, USA). 


\section{Results}

\section{Characteristics of the study sample}

Four hundred ninety two patients were included. This sample was not statistically different from the 3182 patients followed actively in the Aquitaine Cohort in 2004-2005 according to socio-demographics and HIV characteristics (gender, median age, HIV transmission group, years since HIV diagnosis, AIDS stage, hepatitis B and C virus serological status, alcohol and tobacco consumption, CD4 cell count, HIV-RNA serum level, data not shown). There were 359 men (73.0\%); 31 out of the 133 women were in menopausal period (23.3\%). Median age was 43 years (interquartile range [IQR]: 3951 ) for men and 41 years ([IQR]: 38-46) for women ( $p=0.01)$.

The median follow-up since the date of HIV infection diagnosis was 10.9 years ([IQR]: 5.9-15.3) for men and 11.9 years ([IQR]: 6.3-15.2) for women $(p=0.38)$. Men who have sex with men (MSM) were predominant (57.1\%) among male patients followed by heterosexual transmission (19.5\%), whereas $69.9 \%$ of women were classified as cases of heterosexual transmission followed by intravenous drug use (18.1\%). All patients combined, 97 (19.7\%) were at the AIDS stage. The median plasma viral load was $<1.7$ $\log (<50$ copies/mL) (IQR]: $<1.7-3.0)$ and HIV-1 RNA plasma viral load was $<500$ copies $/ \mathrm{mL}$ in 354 patients $(72.0 \%)$. The median rate of $\mathrm{CD} 4^{+}$lymphocytes was 459 cells $/ \mathrm{mm}^{3}$ ([IQR]: 315-643) and 45 patients had $<200$ cells $/ \mathrm{mm}^{3}$; the median nadir (/100) was 2.0 cells $/ \mathrm{mm}^{3}$ ([IQR]: 1.0-3.0). The median calcemia was $2.34 \mathrm{mmol} / \mathrm{L}$ ([IQR]: 2.27-2.41) and the median phosphoremia was $1.06 \mathrm{mmol} / \mathrm{L}$ ([CI]: 0.94-1.18). No patient had major kidney failure (creatinine clearance $>70 \mathrm{~mL} / \mathrm{min}$ for every patient). One hundred and three patients $(21.6 \%)$ had chronic active hepatitis $\mathrm{C}$ (HCV RNA positive), 36 patients (7.6\%) had chronic hepatitis B (HBs antigen positive) and 10 patients $(2.1 \%)$ had chronic hepatitis B and C. $23.8 \%$ of the patients had a daily alcohol consumption $>10$ g per day; among whom, $13(2.7 \%)$ had an excessive consumption ( $>30 \mathrm{~g}$ of alcohol per day). Three-hundred-forty-one patients $(69.7 \%)$ had ever smoked tobacco ( $>1$ cigarette per day) $(73.9 \%$ out of 359 men and $58.6 \%$ out of 133 women $\left.\left(p=5.10^{-3}\right)\right)$ of whom $181(37.0 \%)$ smoked more than 15 pack-years. Only 39 patients $(7.9 \%)$ consumed more than one gram per day of calcium in their diet 
$(\mathrm{N}=423)$. Eighty-two patients $(16.7 \%)$ did not report any physical activity $(<30$ minutes per day); they were more likely to be unemployed, and at the most advanced stages of HIV disease. At the time of the survey, $93.1 \%$ of the patients were on antiretroviral treatment: $80.0 \%$ were treated with NRTI-based HAART, of whom $37.0 \%$ with tenofovir, $28.7 \%$ with NNRTIs and $52.0 \%$ with PIs. The median cumulated duration on treatment was 71.8 months for NRTIs ([IQR]: 30.0-103.0), 7.4 months for NNRTIs ([IQR]: 0.0-30.1) and 20.0 months for PIs (IQR]: 0.0-52.0). Fifty patients (10.2\%) presented at least one pathological fracture, i.e. for a low energy traumatism, acquired before or after the diagnosis of HIV infection. Fifty-seven patients out of 482 (11.8\%) had a BMI $<19 \mathrm{~kg} / \mathrm{m}^{2}$ and 118 patients $(23.4 \%)$ had a BMI $<20.6 \mathrm{~kg} / \mathrm{m}^{2}(19.3 \%$ out of 359 men and $38.8 \%$ out of 133 women $\left.\left(p<10^{-4}\right)\right)$. One hundred-forty patients $(28.5 \%)$ had clinically defined lipodystrophy, 54 of them (11.0\%) had lipoatrophy, $32(6.5 \%)$ had lipoaccumulation and $54(11.0 \%)$ had a mixed syndrome.

The statistically significant differences between men and women were observed for age (men are older), the BMI (women had a smaller BMI) and the tobacco consumption (men smoked more than women). There were no statistical differences on the other parameters described in this paragraph.

Main patient's characteristics are summarised in Tables 1 and 2 for men and women, respectively.

\section{Bone density}

Based on WHO criteria, osteopenia was diagnosed in 264 patients $(53.7 \%), 54.6 \%$ among men (95\% confidence interval [CI]: 49.4-59.7\%) and 51.1\% among women ([CI]: 42.6-59.6\%). Among women, osteopenia was diagnosed in 50.0\% ([CI]: 40.0$60.0 \%)$ and $54.8 \%([\mathrm{CI}]: 37.5-72.5 \%)$ of pre-menopausal and menopausal women respectively. Osteoporosis was diagnosed in 132 patients $(26.8 \%), 33.7 \%$ among men ([CI]: 28.8-38.6\%) and 8.3\% among women ([CI]: 3.6-13.0\%). Among women, osteoporosis was diagnosed in 3.9\% ([CI]: $0.2-7.8 \%)$ and $22.6 \%$ ([CI]: $7.9-37.3 \%)$ of pre-menopausal and menopausal women respectively. Table 3 shows the distribution of median BMD according to gender, site and patients' diagnostic category. Osteoporosis 
predominated at the femoral neck for men (median BMD $0.66 \mathrm{~g} / \mathrm{cm}^{2}$ ) and for women (median BMD $0.59 \mathrm{~g} / \mathrm{cm}^{2}$ ).

\section{Correlates of low bone density}

Among men, the following factors significantly associated with the diagnosis of bone mass loss in the univariable model were included in the multivariable analysis: age, follow-up time since HIV diagnosis, transmission group, AIDS clinical stage, HIV plasma viral load $<500$ copies $/ \mathrm{mL}$, log plasma viral load, tobacco consumption, physical activity, cumulative exposure to antiretroviral class, BMI $<20.6 \mathrm{~kg} / \mathrm{m}^{2}$ and lipodystrophy. Independent factors associated with the diagnosis of osteoporosis were: older age, homosexual HIV transmission, low BMI and HIV plasma viral load $<500$ copies/mL (Table 4). Only older age and lower BMI were marginally associated with osteopenia (Table 4). In women, we pooled together all bone disorders without distinction between osteopenia and osteoporosis because of the reduced number of observations per subgroup. Factors analysed in the multivariable model were: menopausal status, age, follow-up time since HIV diagnosis, transmission group, AIDS clinical stage, HIV plasma viral load $<500$ copies/mL, log plasma viral load zenith, $\mathrm{CD}^{+}$lymphocyte count nadir, alcohol consumption, calcium intake $>1 \mathrm{~g} /$ day, physical activity, cumulative exposure to antiretroviral class and lipodystrophy. Older age (Odds ratio (OR): $1.69,[\mathrm{CI}]: 1.10-2.60, p=0.02)$ and low $\mathrm{CD} 4^{+}$lymphocyte count nadir (OR: 1.43, $[\mathrm{CI}]: 1.10-1.85, p=8.10^{-3}$ were identified as factors associated with reduced BMD. To explore further whether the association between low HIV plasma RNA and osteoporosis in men was related to antiretroviral exposure, we analysed the effect of cumulative exposure to HAART without adjustment for HIV plasma RNA. Three different multivariable models were developed for testing the effect of cumulative exposure to any antiretroviral, cumulative exposure to HAART and naive vs. drugs experienced status, respectively. In the three models the treatment variable effect was not significant whatever the type of variable used (Odds ratio (OR): 1.01, CI: 1.00-1.02, $p=0.07$; OR: 1.02 , CI: $0.95-1.10, p=0.58$; OR: $0.28, \mathrm{CI}: 0.06-1.31, p=0.11$, respectively). Furthermore, this analysis was carried out for each class of drugs: cumulated NRTIs cumulated NNRTIs and cumulated PIs. In these three models, the 
drug class effect was not significant (OR: 1.01, CI: 1.00-1,02, $p=0.06$; OR: 1.01, CI: $1,00-1,03, p=0.43$; OR: 1.01, CI: 1.00-1.03, $p=0.09$, respectively). 


\section{Discussion}

We conducted a cross-sectional survey within the Aquitaine cohort of HIV-infected patients to estimate the prevalence of BMD disorders and to investigate associated factors. Among the 492 patients, representative of the Aquitaine Cohort that were recruited the percentage of bone abnormalities is $80.5 \%$, with $53.7 \%$ of osteopenia and $26.8 \%$ of osteoporosis. Osteoporosis prevalence is high in spite of the young age of the population and reflects well the early demineralization problem faced by HIV-infected patients. This frequency is higher than what has been reported in other studies, with prevalence ranging from $0 \%$ to $22 \%[11,13,18,22-31]$, with narrow boundaries.

Another interesting finding of this osteodensitometry-based survey results is the site of bone demineralization. For men, there is preferentially cortical anatomic osteoporosis, whereas for women, there are trabecular abnormalities. Apart from HIV disease, the male osteoporosis has a cortical predominance, especially in the secondary osteoporosis, whereas classically the post-menopausal osteoporosis is trabecular, first involving the spine. The rare studies having described BMD abnormalities according to the anatomic site had inconclusive results so far $[4,17,24]$.

The main strength of our study is the relatively large number of patients included. Moreover, the number of pathological fractures in this population is $10.2 \%$. No publication provides such an estimate and we identified only some individual case reports [32]. The potential impact of the BMD reduction on the fracture risk remains unknown for the HIV-infected patients. This may be because the majority of them are still young, have few visual or balance problems and are not prone to falls. As the HIVinfected population gets older, the clinicians may see an increase in the fracture rate.

The main limitation to interpret our report is the absence of French references for the Tscore. This could explain the surprising high male prevalence of BMD disorders. Indeed, for women, there is a French reference of BMD values, but for males, with regard to the femoral neck and spine, we had to use American databases for the three anatomic sites. Thus, we may have overestimated the frequency of male osteoporotic events, because the Americans, thanks to their rich diet in vitamin $\mathrm{D}$, have a bone mineralization peak higher than in France. By using an American reference, we are perhaps exceedingly interpreting the results of the whole body and the femoral neck 
BMD. For males, we have also compared the T-scores obtained for the spine with databases with the American T-scores which we would obtain with the French databases, in order to see if the difference was important and it was not statistically significant (data not shown). The gender stratification, imposed by the difference in reference frame between men and women, induced a loss of statistical power of the study since we have two weaker samples. This element partly explains the low number of associated factors highlighted in multivariate analysis.

With regards of the factors found to be associated with BMD, some of them were usual such as older age or lower BMI and others are described for the first time such as homosexual HIV transmission group, low HIV plasma RNA and low CD4 nadir. Biological hypotheses for homosexual transmission group could be that this is a proxy to the abuse of substances that might be toxic for bone metabolism or due to coinfection such as HHV8 (Human Herpes Virus 8) and Kaposi disease. Our result of higher risk of BMD disorder with low plasma viral load is not in agreement with some previously published reports $[15,18]$ that hypothesised a potential role of the virus itself. In our study, the low plasma viral load was the consequence of antiretroviral drug exposure that successfully reduced viral replication. This hypothesis would plead indirectly for a bone harmful effect of treatment itself; but the investigations of the effect of the antiretroviral treatment, unadjusted on the plasma viral load, did not show a significant difference. Thus the effect on bone of the antiretroviral drugs does not explain why the plasma viral load $<500$ arises as a risk factor for the osteoporotic men. The $\mathrm{CD}^{+}$nadir was already studied among HIV-positive women and was not recognized as a factor associated with weakening osteopathies [33]. It is an original finding of our study which goes hand in hand with the severity and length of the immunosuppression, explaining immunological disorders and an increase level of proinflammatory cytokines, inducing modifications of the bone tissue metabolism at the origin of an early demineralization. Another possible interpretation is that patients with a low $\mathrm{CD}^{+}$nadir are those which were treated for a longer period by antiretroviral drugs. This explanation would plead also indirectly for a negative role of antiretroviral drugs on bone metabolism. 
The cumulated exposure to PIs was significantly associated with bone abnormalities in univariate analysis, as for Nolan and Moore [22, 23], but this factor did not hold in the multivariate model. Finally, neither lipodystrophy nor reduced physical activity were associated with early demineralization.

Taking into account the high frequency of diagnosed osteoporosis, it would be useful to propose an osteodensitometry at the HIV-infected patients, in a targeted way, i.e. for the patients cumulating the traditional risk factors of osteoporosis and the specific risk factors of HIV infection highlighted in this study. Moreover, our analysis rather seems to plead for a cortical prevalence of bone demineralization, especially for men, for whom it will be necessary to be particularly vigilant for this risk, looking in particular for occurrence of femoral neck fractures.

Ongoing studies will provide a better knowledge of the physiopathological mechanisms at the origin of early demineralization among HIV-infected patients thus allowing a better diagnostic, preventive and therapeutic evaluation that should be needed in the coming decade of this chronic infection.

\section{Acknowledgements}

This study was supported by a grant from Ensemble contre le SIDA/SIDACTION ( $15^{\text {th }}$ call for proposals). The Aquitaine cohort is supported by a multi-year grant of the French Agency for Research on AIDS and viral Hepatitis (ANRS).

\section{Appendix}

Preliminary results have been presented in part at the 3rd IAS Conference on HIV Pathogenesis and Treatment (Rio de Janeiro), 2005 (abstract TuPe2.2B19) and at the 13th Conference on Retroviruses and Opportunistic Infections (Denver), 2006, (abstract 229). 


\section{References}

[1] Palella FJ Jr, Delaney KM, Moorman AC, Loveless MO, Fuhrer J, Satten GA, et al. Declining morbidity and mortality among patients with advanced human immunodeficiency virus infection. HIV Outpatient Study Investigators. N Engl J Med. 1998; 338:853-60.

[2] Carr A, Samaras K, Burton S, Law M, Freund J, Chrisolm DJ, et al. A syndrome of peripheral lipodystrophy, hyperlipidemia and insuline resistance in patients receiving HIV protease inhibitors. AIDS 1998; 12:F518.

[3] Tebas P, Poxderly WG, Claxton S, Marin D, Tantisiriwat W, Teitebaulm SL, et al. Accelerated bone mineral loss in HIV-infected patients receiving potent antiretroviral therapy. AIDS 2000; 14:F63-7.

[4] Knobel H, Guelar A, Valecillo G, Nogues X, Diez A. Osteopenia in HIVinfected patiens: is-it the disease or is it the treatment? AIDS 2001; 15:8078.

[5] Brown TT, Qaqish RB. Antiretroviral therapy and the prevalence of osteopenia and osteoporosis: a meta-analytic review. AIDS. 2006; 20:216574.

[6] Mondy K, Tebas P. Emerging bone problems in patients infected with human immunodeficiency virus. Clin Infect Dis 2003; 36 (Suppl 2):S101-5.

[7] Mondy K, Yarasheski K, Powderly WG, Whyte M, Claxton S, DeMarco D, et al. Longitudinal evolution of bone mineral density and bone markers in human immunodeficiency virus-infected individuals. Clin Infect Dis. 2003; 36:482-90.

[8] McDermott AY, Terrin N, Wanke C, Skinner S, Tchetgen E, Shevitz AH. CD4 ${ }^{+}$ cell count, viral load, and highly active antiretroviral therapy use are independent predictors of body composition alterations in HIV-infected adults: a longitudinal study. Clin Infect Dis 2005; 41:1662-70.

[9] Bongiovanni M, Fausto A, Cicconi P, Aliprandi A, Cornalba G, Bini T, et al. Non-nucleoside-reverse-transcriptase-inhibitor-based HAART and 
osteoporosis in HIV-infected subjects. J Antimicrob Chemother. 2006; 58:485-6.

[10] Amorosa V, Tebas P. Bone disease end HIV infection. Clin Infect Dis 2006; 42:108-114.

[11] Arnsten JH, Freeman R, Howard AA, Floris-Moore M, Santoro N, Schoenbaum EE. HIV infection and bone mineral density in middle-aged women. Clin Infect Dis 2006; 42:1014-20.

[12] Bolland MJ, Grey AB, Horne AM, Briggs SE, Thomas MG, Ellis-Pegler RB, et al. Bone mineral density is not reduced in HIV-infected Caucasian men treated with highly active antiretroviral therapy. Clin Endocrinol 2006; 65:191-7.

[13] Overton ET, Mondy K, Bush T, Conley L, Kojic E, Henry K, et al. Factors Associated with Low Bone Mineral Density in a Large Cohort of HIVinfected US Adults: Baseline Results from the SUN Study. Abstract 836. 14th Conference on Retroviruses and Opportunistic Infections, Los Angeles, February 2007.

[14] Kühne CA, Heufelder AM, Hofbauer LC. Bone and mineral metabolism in human immunodeficiency virus infection. J Bone Miner Res 2001; 16:2-9.

[15] Fessel WJ, Hurley LB. Is HIV sequestered in bone? Possible implications of virological and immunological findings in some HIV-infected patients with bone disease. AIDS 2003; 17:255-257.

[16] Cozzolino M, Vidal M, Arcidiacono MV, Tebas P, Yarashesky KE, Dusso AS. HIV-protease inhibitors impair vitamin $D$ bioactivation to $1,25-$ dihydroxyvitamin D. AIDS 2003; 17:513-20.

[17] Amiel C, Ostertag A, Slama L, Baudoin C, N'Guyen T, Lajeunie E, et al. BMD is reduced in $\mathrm{HIV}$-infected men irrespective of treatment. J Bone Miner Res 2004; 19:402-9.

[18] Fausto A, Bongiovanni M, Cicconi P, Menicagli L, Ligabo EV, Melzi S, et al. Potential predictive factors of osteoporosis in HIV-positive subjects. Bone 2006; 38:893-7.

[19] Thiebaut R, Morlat P, Jacqmin-Gadda H, Neau D, Mercie P, Dabis F, et al. Clinical progression of HIV-1 infection according to the viral response 
during the first year of antiretroviral treatment. Groupe d'Epidemiologie du SIDA en Aquitaine (GECSA). AIDS 2000; 14:971-8.

[20] Kelly T. Bone mineral density reference databases for American men and women. J Bone Miner Res 1990; Res5:S249.

[21] Kanis JA. Assessment of fracture risk and its application to screening for postmenopausal osteoporosis: synopsis of a WHO report. WHO Study Group. Osteoporos Int 1994; 4:368-81.

[22] Nolan D, Upton R, McKinnon E, John M, James I, Adler B, et al. Stable or increasing bone mineral density in HIV-infected patients treated with nelfinavir or indinavir. AIDS 2001; 15:1275-80.

[23] Moore AL, Vashisht A, Sabin CA, Mocroft A, Madge S, Phillips AN, et al. Reduced bone mineral density in HIV-positive individuals. AIDS 2001; 15:1731-3.

[24] Carr A, Miller J, Eisman JA, Cooper DA. Osteopenia in HIV-infected men: association with asymptomatic lactic acidemia and lower weight preantiretroviral therapy. AIDS 2001; 15:703-9.

[25] Bruera D, Luna N, David DO, Bergoglio LM, Zamudio J. Decreased bone mineral density in HIV-infected patients is independent of antiretroviral therapy. AIDS 2003; 17:1917-23.

[26] Dolan SE, Huang JS, Killilea KM, Sullivan MP, Aliabadi N, Grinspoon S. Reduced bone density in HIV-infected women. AIDS 2004; 18:475-83.

[27] Brown TT, Ruppe MD, Kassner R, Kumar P, Kehoe T, Dobs AS, et al. Reduced bone mineral density in human immunodeficiency virus-infected patients and its association with increased central adiposity and postload hyperglycemia. J Clin Endocrinol Metab 2004; 89:1200-1206.

[28] Seminari E, Castagna A, Soldarini A, Galli L, Fusetti G, Dorigatti F, et al. Osteoprotegerin and bone turnover markers in heavily pretreated HIVinfected patients. HIV Med 2005; 6:145-50.

[29] Konishi M, Takahashi K, Yoshimoto E, Uno K, Kasahara K, Mikasa K. Association between osteopenia/osteoporosis and the serum RANKL in HIV-infected patients. Aids 2005; 19:1240-1. 
[30] Bongiovanni M, Fausto A, Cicconi P, Menicagli L, Melzi S, Ligabo VE, et al. Osteoporosis in HIV-infected subjects: a combined effect of highly active antiretroviral therapy and HIV itself? J Acquir Immune Defic Syndr 2005; 40:503-4.

[31] Garcia Aparicio AM, Munoz Fernandez S, Gonzalez J, Arribas JR, Pena JM, Vazquez JJ, et al. Abnormalities in the bone mineral metabolism in HIVinfected patients. Clin Rheumatol 2006; 25:537-9.

[32] Guaraldi G, Ventura P, Albuzza M, Orlando G, Bedini A, Amorico G, et al. Pathological fractures in AIDS patients with osteopenia and osteoporosis induced by antiretroviral therapy. AIDS 2001; 15:137-8.

[33] Yin M, Dobkin J, Brudney K, Becker C, Zadel JL, Manandhar M, et al. Bone mass and mineral metabolism in HIV+ postmenopausal women. Osteoporos Int. $2005 ; 16: 1345-52$. 
Table 1. Men characteristics according to the diagnostic categories of bone mineral density, ANRS CO 3 Aquitaine Cohort, France

\begin{tabular}{|c|c|c|c|c|c|c|}
\hline \multirow[t]{2}{*}{ MEN characteristics } & Total & No abnormality & Osteopenia $^{* 1}$ & Osteoporosis $^{* 1}$ & \multirow[t]{2}{*}{$p^{* 2}$} & \multirow[t]{2}{*}{$\mathbf{p}^{* 3}$} \\
\hline & $\%$ or median [IQR] & $\%$ or median [IQR] & $\%$ or median [IQR] & $\%$ or median $[\mathrm{IQR}]$ & & \\
\hline $\mathbf{N}=\mathbf{3 5 9}(100 \%)$ & & 11.7 & 54.6 & 33.7 & & \\
\hline $\begin{array}{l}\text { Transmission group } \\
\text { Homosexuality } \\
\text { Heterosexuality } \\
\text { Intravenous drug use } \\
\text { Other }\end{array}$ & $\begin{array}{c}57.1 \\
19.5 \\
13.9 \\
9.5\end{array}$ & $\begin{array}{l}47.6 \\
23.8 \\
14.3 \\
14.3\end{array}$ & $\begin{array}{l}57.6 \\
18.9 \\
13.3 \\
10.2\end{array}$ & $\begin{array}{c}59.5 \\
19.0 \\
14.9 \\
6.6\end{array}$ & 0.40 & 0.75 \\
\hline Follow-up since HIV diagnosis (years) & $10.9[5.9-15.3]$ & $9.5[3.8-14.1]$ & $10.9[5.9-14.8]$ & $11.2[6.5-15.4]$ & 0.32 & 0.79 \\
\hline AIDS clinical stage & 21.5 & 9.5 & 22.5 & 24.0 & 0.11 & 0.75 \\
\hline BMI $<20.6 \mathrm{~kg} / \mathrm{m}^{2 * 4}$ & 19.3 & 7.1 & 13.4 & 33.3 & $1.3 .10^{-5}$ & $<10^{-4}$ \\
\hline Lipodystrophy & 27.6 & 19.1 & 23.5 & 37.2 & 0.01 & $9.10^{-3}$ \\
\hline $\begin{array}{l}\text { Tobacco consumption } \\
\text { Severe }(>15 \mathrm{PY}) \\
\text { Moderate } \\
\text { No }\end{array}$ & $\begin{array}{l}38.8 \\
35.1 \\
26.1\end{array}$ & $\begin{array}{l}26.2 \\
42.9 \\
30.9\end{array}$ & $\begin{array}{l}40.0 \\
33.3 \\
26.7\end{array}$ & $\begin{array}{l}41.2 \\
35.3 \\
23.5\end{array}$ & 0.20 & 0.84 \\
\hline HIV RNA plasma viral load $<500$ copies $/ \mathbf{m L}$ & 72.4 & 61.9 & 71.9 & 76.9 & 0.17 & 0.33 \\
\hline $\mathrm{CD}^{+}$count $<200 / \mathrm{mm}^{3}$ & 9.5 & 14.3 & 7.1 & 11.6 & 0.22 & 0.18 \\
\hline $\mathrm{CD4}^{+} \operatorname{nadir}(/ 100)\left(\right.$ cells $\left./ \mathrm{mm}^{3}\right)$ & $2.0[1.0-3.0]$ & $2.0[1.0-3.0]$ & $2.0[1.0-3.0]$ & $2.0[1.0-3.0]$ & 0.66 & 0.37 \\
\hline NRTI cumulative exposure (months) & $71.2[28.4-99.0]$ & $47.9[16.0-89.7]$ & $76.1[29.0-102.5]$ & $75.0[35.6-101.6]$ & 0.05 & 0.61 \\
\hline NNRTI cumulative exposure (months) & $7.0[0.0-30.0]$ & $5.2[0.0-21.4]$ & $8.7[0.0-21.7]$ & $7.0[0.0-29.8]$ & 0.59 & 0.82 \\
\hline PI cumulative exposure (months) & $18.9[0.0-49.8]$ & $3.0[0.0-32.9]$ & $15.6[0.0-51.3]$ & $29.0[0.0-51.2]$ & 0.06 & 0.34 \\
\hline
\end{tabular}

IQR: interquartile range; BMI: body mass index; NRTI: nucleoside and nucleotide reverse transcriptase inhibitor; NNRTI: non nucleoside transcriptase inhibitor; PI: protease inhibitor; PY: pack-year. ${ }^{* 1}$ See definition in Methods. ${ }^{* 2}$ Comparison of the 3 groups (Kruskal-Wallis test for quantitative variables, Chi-Square test for qualitative variables). ${ }^{*}$ Comparison osteopenia versus osteoporosis (Wilcoxon test for quantitative variables, Chi-Square or Fisher's Exact test for qualitative variables). ${ }^{* 4}$ For reasons of statistical significativity the selected BMI threshold was $20.6 \mathrm{~kg} / \mathrm{m}^{2}$ that corresponds to the first quartile of the distribution of all the BMI values. 
Table 2. Women characteristics according to diagnosis category of bone mineral density, ANRS CO 3 Aquitaine Cohort, France.

\begin{tabular}{|c|c|c|c|c|c|c|}
\hline \multirow[t]{2}{*}{ WOMEN characteristics } & Total & No abnormality & Osteopenia $^{* 1}$ & Osteoporosis $^{* 1}$ & $p^{* 2}$ & $p^{* 3}$ \\
\hline & $\%$ or median [IQR] & $\%$ or median [IQR] & $\%$ or median [IQR] & $\%$ or median [IQR] & & \\
\hline$N=133$ & & 40.6 & 51.1 & 8.3 & & \\
\hline Menopause & 23.3 & 13.0 & 25.0 & 63.6 & $2.10^{-3}$ & 0.02 \\
\hline Age (years) & $41.0[38.0-46.0]$ & $39.0[34.0-43.0]$ & $42.0[39.0-48.0]$ & $58.0[40.0-70.0]$ & $3.10^{-4}$ & $10^{-2}$ \\
\hline $\begin{array}{l}\text { Transmission group } \\
\text { Heterosexuality } \\
\text { Intravenous drug use } \\
\text { Other }\end{array}$ & $\begin{array}{l}69.9 \\
18.1 \\
12.0\end{array}$ & $\begin{array}{c}77.8 \\
16.7 \\
5.6\end{array}$ & $\begin{array}{l}67.7 \\
19.1 \\
13.2\end{array}$ & $\begin{array}{l}45.4 \\
18.2 \\
36.4\end{array}$ & 0.09 & 0.15 \\
\hline Follow-up since HIV diagnosis (years) & $11.9[6.3-15.2]$ & $10.6[4.2-14.1]$ & $12.5[8.3-15.6]$ & $13.1[8.1-15.8]$ & 0.07 & 0.96 \\
\hline AIDS clinical stage & 15.0 & 9.3 & 19.1 & 18.2 & 0.26 & 1.00 \\
\hline BMI $<20.6 \mathrm{~kg} / \mathrm{m}^{2}$ & 38.8 & 34.0 & 40.0 & 54.6 & 0.42 & 0.37 \\
\hline Lipodystrophy & 30.8 & 22.2 & 33.8 & 54.6 & 0.08 & 0.19 \\
\hline $\begin{array}{l}\text { Tobacco consumption } \\
\text { Severe }(>15 \mathrm{PY}) \\
\text { Moderate } \\
\text { No }\end{array}$ & $\begin{array}{l}32.3 \\
26.3 \\
41.4\end{array}$ & $\begin{array}{l}31.5 \\
27.8 \\
40.7\end{array}$ & $\begin{array}{c}9.1 \\
27.3 \\
63.6\end{array}$ & $\begin{array}{l}36.8 \\
25.0 \\
38.2\end{array}$ & 0.19 & 0.09 \\
\hline HIV RNA plasma viral load $<500$ copies $/ \mathrm{mL}$ & 70.7 & 64.8 & 72.1 & 90.9 & 0.23 & 0.27 \\
\hline $\mathrm{CD}^{+}$count $<200 / \mathrm{mm}^{3}$ & 8.3 & 9.3 & 7.4 & 9.1 & 0.90 & 1.00 \\
\hline CD4 $^{+}$nadir $(/ 100)\left(\right.$ cells $\left./ \mathrm{mm}^{3}\right)$ & $2.0[1.0-3.0]$ & $2.0[2.0-4.0]$ & $2.0[1.0-3.0]$ & $1.5[0.0-3.0]$ & $8.10^{-3}$ & 0.99 \\
\hline NRTI cumulative exposure (months) & $73.1[36.3-110.3]$ & $61.5[25.9-104.5]$ & $80.7[40.9-112.4]$ & $77.6[36.9-117.2]$ & 0.42 & 0.80 \\
\hline NNRTI cumulative exposure (months) & $9.0[0.0-30.3]$ & $1.8[0.0-23.8]$ & $12.1[0.0-31.2]$ & $33.5[22.5-61.6]$ & 0.04 & 0.05 \\
\hline PI cumulative exposure (months) & $11.5[0.0-54.5]$ & $3.0[0.0-20.3]$ & $19.4[0.0-65.1]$ & $20.6[0.0-62.2]$ & 0.06 & 0.73 \\
\hline
\end{tabular}


Table 3. Median BMD according to gender, site and patients' diagnostic category, ANRS CO 3 Aquitaine Cohort, France.

\begin{tabular}{ccccc}
\hline \multirow{2}{*}{ Site } & Gender & \multicolumn{3}{c}{ BMD $\left(\mathbf{g} / \mathbf{c m}^{2}\right)($ Median $[\mathrm{IQR}])$} \\
\cline { 3 - 5 } & & $\begin{array}{c}\text { No abnormality } \\
(\mathrm{T} \text {-score }>-1) \\
(\mathrm{n}=96)\end{array}$ & $\begin{array}{c}\text { Osteopenia } \\
(-2.5 \leq \mathrm{T} \text {-score } \leq-1) \\
(\mathrm{n}=264)\end{array}$ & $\begin{array}{c}\text { Osteoporosis } \\
(\mathrm{T} \text {-score }>-2.5) \\
(\mathrm{n}=132)\end{array}$ \\
\hline \multirow{2}{*}{ Total body } & M & $\mathbf{1 . 2 6}[1.22 ; 1.29]$ & $\mathbf{1 . 1 6}[1.12 ; 1.20]$ & $\mathbf{1 . 0 6}[1.00 ; 1.10]$ \\
& W & $\mathbf{1 . 1 6}[1.12 ; 1.21]$ & $\mathbf{1 . 0 5}[1.00 ; 1.11]$ & $\mathbf{0 . 9 3}[0.87 ; 0.95]$ \\
Femoral neck & M & $\mathbf{0 . 9 2}[0.90 ; 0.98]$ & $\mathbf{0 . 7 7}[0.73 ; 0.82]$ & $\mathbf{0 . 6 6}[0.61 ; 0.69]$ \\
& W & $\mathbf{0 . 8 4}[0.79 ; 0.89]$ & $\mathbf{0 . 6 9}[0.64 ; 0.74]$ & $\mathbf{0 . 5 9}[0.54 ; 0.64]$ \\
Lumbar spine & M & $\mathbf{1 . 1 1}[1.06 ; 1.18]$ & $\mathbf{0 . 9 9}[0.94 ; 1.05]$ & $\mathbf{0 . 8 7}[0.78 ; 0.93]$ \\
& W & $\mathbf{1 . 0 8}[1.03 ; 1.15]$ & $\mathbf{0 . 9 4}[0.87 ; 1.01]$ & $\mathbf{0 . 8 0}[0.74 ; 1.00]$ \\
\hline
\end{tabular}

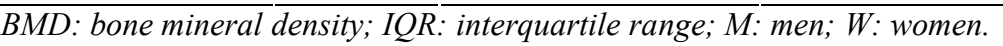


Table 4: Factors associated with osteopenia and osteoporosis in multivariate analysis in HIV-infected men $(n=317)$, compared to those without bone abnormality $(n=42)$, ANRS CO 3 Aquitaine Cohort, France.

\begin{tabular}{|c|c|c|c|c|}
\hline & \multicolumn{2}{|c|}{$\begin{array}{l}\text { Osteopenia } \\
(n=194)\end{array}$} & \multicolumn{2}{|c|}{$\begin{array}{l}\text { Osteoporosis } \\
\quad(n=117)\end{array}$} \\
\hline & OR $(95 \% \mathrm{CI})$ & $p$-value & OR $(95 \% \mathrm{CI})$ & p-value \\
\hline Age (by 10 years older) & $1.46(0.99-2.15)$ & 0.06 & $2.03(1.33-3.08)$ & $9.10^{-4}$ \\
\hline $\begin{array}{l}\text { Transmission group } \\
\text { Homosexuality } \\
\text { Heterosexuality } \\
\text { Intravenous drug use } \\
\text { Other }\end{array}$ & $\begin{array}{l}\text { ref } \\
0.58(0.24-1.38) \\
0.63(0.23-1.77) \\
0.34(0.11-1.06)\end{array}$ & 0.26 & $\begin{array}{l}\text { ref } \\
0.51(0.19-1.32) \\
0.57(0.18-1.74) \\
0.14(0.04-0.52)\end{array}$ & 0.01 \\
\hline Body mass index $<20.6 \mathrm{~kg} / \mathrm{m}^{2}$ & $3.31(0.86-12.69)$ & 0.08 & $14.4(3.68-56.71)$ & $10^{-4}$ \\
\hline HIV plasma viral load $<500 \mathrm{cp} / \mathrm{mL}$ & $1.82(0.88-3.77)$ & 0.11 & $2.62(1.16-5.94)$ & 0.02 \\
\hline
\end{tabular}

OR: odds ratio; CI: confidence interval; cp: copies. 